\title{
HISTORY OF THE DATIVE MARKERS IN KOREAN LANGUAGE: FROM OLD KOREAN TO CONTEMPORARY KOREAN
}

\author{
Olivier BAILBLÉ \\ Hankuk University of Foreign Studies ${ }^{24}$ \\ Department of Chinese Language and Culture, \\ 107 Imun-ro, Dongdaemun-gu, Seoul 130-791, South Korea. \\ Olivier.bailble@ hotmail.fr
}

\begin{abstract}
The focus of this paper and the intention of the author are to show in a diachronic perspective how the dative markers in Korean Language have changed and evolved during two thousand years of history. The rise of new writing systems during $8^{\text {th }}$ century such as $\mathrm{Idu}^{25}$ and also the difference of the structure of the language between Chinese and Korean bring different conclusions. In particular, this paper will focus on the different grammatical origins of dative markers and additionally the morphological changes will be shown in those structures, especially with the rise of the Korean Alphabet in $15^{\text {th }}$ century.
\end{abstract}

Key words: Datives Markers, Early Middle Korean, Chinese Characters, Idu Writing System

Résumé en français: Cette étude cherche à montrer l'évolution des marqueurs du datif en coréen dans une perspective diachronique. Il y a deux mille ans, les Coréens ont commencé par utiliser une écriture qui leur était étrangère, à savoir les caractères

\footnotetext{
24 This paper was supported by Hankuk University of Foreign Studies research fund of 2014.

${ }^{25} \mathrm{Idu}$ is an archaic writing system used between the $8^{\text {th }}$ and $19^{\text {th }}$ century in Korean. Chinese characters had to indicate Korean verb endings and other grammatical markers that were different in Korean from Chinese Language.
} 
chinois. Les documents étant très peu nombreux, on doit toutefois attendre le Ve siècle avec la stèle de Kwanggaet'o pour voir apparaitre les premières formes de marqueurs du datif. Mais le texte est entièrement écrit en utilisant la grammaire du chinois de Chinois, et sa lecture est donc difficile. C'est pour cette raison qu'à partir de cette époque, les Coréens vont modifier la structure du chinois classique et l'adapter à celle du coréen. Cette mutation sera symbolisée avec l'avènement des Idu «lecture pour les fonctionnaires ». Le système Idu permet en effet de retranscrire les formes grammaticales du coréen absentes dans les textes antiques. Vers le XIIe siècle, on arrive d'ailleurs à identifier clairement un marqueur du datif issu du système Idu. Le système d'écriture va connaitre une autre évolution importante avec la création de l'alphabet coréen. Des lors, la plupart des marqueurs grammaticaux autrefois exprimés à l'aide des caractères chinois dans le cadre du Idu vont disparaitre pour la plupart et être remplacés par le H'angeul. Les marqueurs du datif ne feront pas exception à la règle, on verra par ailleurs que beaucoup de ces termes possèdent des origines bien différentes. Le coréen, imprégné par le confucianisme devra en effet conjuguer les marqueurs du datif avec des degrés de politesse propre à une société hiérarchisée. Ces origines, nous les retrouvons aujourd'hui dans le coréen contemporain, qui sont précisément utilisées en fonction de la personne à qui l'on s'adresse.

Mots clés: marqueurs du datif, coréen pré médiéval, caractères chinois, Idu.

한국어 여격조사의 역사: 고대한국어에서부터 현대한국어까지

개략: 이 연구는 한국어 여격의 변화를 통시적 관점에서 다루고 있다. 이천 년 전 한국인들은 외국에서 온, 다시 말해 한자를 사용하기 시작하였다. 풍부하지 않은 자료로 첫 번째 여격의 초기형태를 엿보기 위해서는 5 세기 광개토대왕의 비문을 참고해야만 한다. 하지만 광개토왕의 비문의 글은 중국어 문법에 따라 한자어로 쓰여 있어 문장에 대한 판독은 쉽지 않다. 바로 이러한 이유로 그 시대부터 한국사람들은 전통적인 한자어 구조를 한국어의 구조에 맞게 변경하기 시작하였다. 이러한 변화는 이두 표기법 (관료들의 문자) 의 출현에서 엿볼 수 있다. 이두 표기법은 고대의 텍스트에 존재하지 않은 한국어의 문법적인 형태를 재현해주고 있다. 게다가 12 세기경에는 우리는 이두 표기법의 여격에서 분명하게 이 변화를 알아볼 수 있다. 한편 이두 표기법은 훈민정음 창제로 또 다른 중요한 발전을 맞이하게 된다. 이두 표기법으로 표현된, 중국어의 차용으로 표기된 조사는 대다수 한글로 대체되어 사라지게 된 것이다. 여격 또한 이 변화에 예의 없이 원래의 기원과는 많이 달라진 형태를 보여준다. 유교사상의 결합으로 생긴 사회계층에 의한 높임말에 변화에 따라 여격의 변화가 생기는 것이다. 이러한 기원은 우리가 누구와 대화하느냐에 따라 다르게 표현되는 현대 한국어에서 쉽게 찾아볼 수 있다.

키워드: 여격조사; 중세한국어; 한자; 이두. 


\section{Chinese Archaic Period: $1200 \mathrm{BC}$ to $300 \mathrm{BC}$ (shànggǔ hànyǔ上古漢語)}

We have various dative constructions in Archaic Chinese which are identified (Peyraube, 1986:27). There are three main dative structures in Archaic Chinese and two main dative markers: yú 于 and Yr̃ 以

- $\mathrm{V}+\mathrm{IO}+\mathrm{DO}^{26}$

- $\quad \mathrm{V}+\mathrm{DO}+$ yú 于+IO

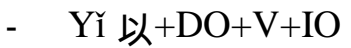

Those structures concern the period called "Proto-Korean" (Ān and Shàng 2009: 54-7) but Chinese Characters were introduced into the Korean Peninsula around 100 BC. Nevertheless, it's interesting to see the evolution of the dative constructions since the Archaic Period.

\subsection{Historical Background}

China established four garrisons for almost four centuries from 108 B.C. to 314 in order to control this area. Kokuryŏ (37 BC-668 AD) ${ }^{27}$, slowly began to conquer the garrisons and eventually absorbed them into its own territory (Fabre, 2001:23).

\footnotetext{
${ }^{26}$ IO: Indirect Object and DO is Direct Object.

${ }^{27}$ The Three Kingdoms of Korea refers to the ancient Korean kingdoms of Kokuryŏ, Baekje and Silla, which dominated the Korean peninsula and parts of Manchuria for much of the $1^{\text {st }}$ millennium. The Three Kingdoms period ran from 57 AD until Silla's triumph over Kokuryŏ in 668.
} 


\subsection{Language}

Early Old Korean corresponds to the period where Korean people are going to use a writing system for the first time: Chinese Characters (Hancha). There is also unification of the Korean Language, one in the southern part, the "Han Language", and one in the northern part, the "Kokuryŏ Language". This is the first period of transformation of the Korean Language ${ }^{28}$.

\subsection{Data}

The three main structures of the classical period described by Peyraube are still followed and a new construction emerged: V1+V2+IO+DO (see the texts of Sī Măqiān in Shǐjì) ${ }^{29}$. Concerning

\footnotetext{
${ }^{28}$ In North Korea, it is believed by some scholars for example (Ryu Ryŏl 1994) that the Korean people had their own written alphabet before the use of Chinese characters. In a written work from the $15^{\text {th }}$ century entitled, "Dragon Flying to the Guardian of the Sky", Sinji is given credit for having created a 16 alphabet letters. Legend records that Sinji, had gone hunting one day, found traces of a deer, and received inspiration to the point of making an alphabet. In North Korean hagiography, Sinji generally represents the image of a man "powerful", "a ruler", or "a great sovereign". In South Korea it is said that these sixteen letters of the alphabet Sinjŏn somehow represent an ancestor to Hangŭl (the Korean alphabet) for North Koreans. Legend notwithstanding, what came into existence was a sixteen letter alphabet (Sinjon) which thus formed a Korean means of writing, separate and distinct, from Chinese characters. However, over time there has been much difficulty in finding the exact use of Sinjŏn and its components namely its system, its alphabetical order, the phonetic value of each word, etc. Little or no reference, outside of the legend has been made to its existence in literary works from South Korea. Although the issue remains a sensitive one for the people of South Korea, the theory of pre-existing writing ideograms remains an issue. This question remains sensitive cause in the South, where everybody learns that King Sejong is the creator of the Korean Alphabet.
}

${ }^{29}$ Old Korean is the equivalent of Early Middle Chinese (300 BC to 600). 
Korean data itself, we have to wait until the $5^{\text {th }}$ century in order to have materials written by Koreans in Classical Chinese ${ }^{30}$. In the $5^{\text {th }}$ century, Chinese characters are used officially as a written language in Korea. The first text we find written by the Koreans is the stele of the king Kwanggaet'o (414) which is a description of the victory against the Manchu and the Wa (Japanese). Here is an example of the dative case in Old Korean.

(1) 顧命世子儒留王與治

gù mìng shìzi rú liú wáng yǔ zhì

minister-entrusted - crown - King Yuryu - give- command

He left the power command to King Yuryu.

2. Late Old Korean ( $7^{\text {th }}$ to $10^{\text {th }}$ century)

\subsection{Historical Background}

Unified Silla (668-935) is the name often applied to the Korean kingdom of Silla when it conquered Paekche and Kokuryŏ. The cultural influence of China is increasingly important. During this period, many native words are replaced by Chinese lexical items such as "river":

Example: 강 kang from Chinese lexicon 江 jiāng "river". (Old name was 가람 karam).

\subsection{Language}

\footnotetext{
${ }^{30}$ However, "The song of the yellow bird" is supposedly composed by King Yuri around the $1^{\text {st }}$ century A.D. but we cannot find any dative markers in this poem.
} 
In the $7^{\text {th }}$ century, Koreans started to realize that the structure of Korean language does not fit with the one in Chinese. Korean Language is supposed to belong to Ural-Altaic Language with a SOV structure while Chinese Language is originated from Sino-Tibetan Language Family with a SVO structure. The most important difference is that Chinese is an isolating language while Korean is an agglutinative one. So the lecture of Classical Chinese by Korean scholars is very difficult. In order to make the reading easier, Koreans have decided to create new writing systems. It is called Idu or Lìdú (吏讀) in Chinese.

(1) First period: around $5^{\text {th }}$ century

Hyanch'al System writing: "Local Letters" (Hyangch'al)

Hyangch'al is an archaic writing system of Korea and was used to transcribe the Korean Language into Chinese Characters. Under the Hyangch'al system, Chinese characters were given a Korean reading based on the syllable associated with the character. Called "Vernacular Letters" or "Local Letters", this ancient form of writing borrows the meaning of the character and sometimes its pronunciation. These "Local Letters" were more intended to represent poetry or traditional Korean songs. From the 6th century, we can say not only that Chinese writing not only has gained a foothold in the Korean language, but it is also the time when the loan words from Chinese lexicon really make their appearance. During Unified Silla ${ }^{31}(668$ - 935), new types of writing system appeared.

(2) Second Period: around 7th century

Idu writing system: "Lecturer for public officer"

\footnotetext{
${ }^{31}$ Unified Silla is the name often applied to the Korean kingdom of Silla, one of the Three Kingdoms of Korea when it conquered Baekje in 660 and Kokuryo in 668, unifying the southern portion of the Korean peninsula. Its last king, ruling over a state in name only, submitted to the emerging Koryo in 935 , bringing the dynasty to an end.
} 
Idu is an archaic writing system that represents the Korean language using Chinese characters. The Idu script used the Chinese characters along with special symbols to indicate Korean verb endings and other grammatical markers that were different in Korean from Chinese (Nam, 2000: 57). In a broad sense, Idu is a term that refers to all borrowings of Chinese characters; it is a use of Chinese characters adapted to Korean grammar. It was during this period $\left(8^{\text {th }}\right.$ and $9^{\text {th }}$ century) that Korean people began to combine Chinese and Korean. Terms are expressed in Chinese characters, and suffixes and auxiliaries in Korean. This system had the advantage of being used for more than eight centuries before the use of the current Korean alphabet. This monk Sŏl Chong is usually presented as the inventor of this writing system. In the late $8^{\text {th }}$ century, between these two systems emerged another mode of writing.

\subsection{Data}

As we mentioned before, Buddhism spread over the peninsula. Two monks, Wonhyo and Uisang, symbolize this phenomenon (Lee, 1992). From this period of time, most of the texts and documents have disappeared. For instance, only 25 poems remain but we cannot find any dative marker in them. 
3. Early Middle Korean: $10^{\text {th }}$ to $14^{\text {th }}$ century (전기 중세한국어 前期 中世韓國語)

\subsection{Historical background}

Koryŏ was a Korean dynasty established in 918 by King Taejo. The cultural and the political influence of Song China were increasingly influential. In 958, King Kwangjong set up the national civil service examinations. These tests measured candidates' knowledge of the Chinese classics. Buddhism and Confucianism had also a strong impact on the Korean peninsula.

\subsection{Language}

During the Koryo dynasty the Chinese Korean lexicon took shape. The Idu writing system and the influence of the Chinese lexicon over the native words in Korean are very important. Meanwhile, another writing system is created in Koryŏ dynasty called Kukyŏl (Na, 2008:63). Unlike the Idu and Hyangch'al systems which preceded it, Kukyŏl used specialized markings, together with a subset of Chinese characters, to represent Korean morphological markers. Also, the Idu and Hyangch'al systems appear to have been used primarily to render the Korean language into Chinese characters; on the other hand, Kukyŏl sought to render Chinese texts into Korean with a minimum of distortion. 


\subsection{Data}

In Early Middle Korean, we can identify one dative marker: yŏkchung (역중亦中). We can notice here that the size of the Chinese Character to express grammatical markers is smaller than the rest of the sentences below. That is also the case for the dative marker in Korean (Ko, 1977).

（2）出父狄三亦子息亦中奴婢分給決 ch'ulbuchŏksamyŏk chashikdŭngyŏkchung nobibunkŭbkyŏl father-chŏksam- subject marker- son-dative marker- slavedistribute-decide

Father Chŏksam (his name) has decided to offer a servant to his son.

（南氏奴婢文書 2-4;1382）

Another example:

出子奴龍萬亦中傳許與身故

Chulchanolongman yŏkchung chosuyŏk shingo

Long man father-dative marker- give- dead body (They) gave to Longman's father the dead body.

（南氏奴婢文書 7-8;1382）

4. Late Middle Korean: $14^{\text {th }}$ to $16^{\text {th (後期中世韓國語) }}$

4.1. Historical background:

The Chosŏn Dynasty, founded in 1392 by the Korean General Yi Sŏng-Kye, overthrew the Koryŏ Kingdom and at the same time ended 
Mongol domination which had lasted until the 1350s. During its reign, Chosŏn consolidated its effective rule over the territory of current Korea, encouraged the entrenchment of Korean Confucian ideals and doctrines in Korean society, imported and adapted Chinese culture, and saw the height of classical Korean culture, trade, science, literature, and technology.

\section{Language:}

King Sejong profoundly affected Korean history with his introduction of Hangul, the native phonetic alphabet system for the Korean language. Before the creation of Hangul, only members of the highest class were literate (hanja was typically used to write Korean by using adapted Chinese characters, while Hanmun was sometimes used to write court documents in classical Chinese). Late Middle Korean sees the rise of the Korean Alphabet. During that period, we can observe origins among the dative markers in Korean language: verb, noun, demonstrative pronoun (Cho, 2008).

\subsection{Data}

Dative constructions originating from demonstrative Pronoun: 의 그어기

In Late Middle Korean, the locative demonstrative pronoun turned to be used as a dative marker.

- General Form: 의 그어귀

$$
\begin{aligned}
& \text { 病人으로그어긔 소변을 누워 나잘만 두면 [구급 하:17] } \\
& \text { (1489). } \\
& \text { byŏngin ŭro kŭŏkŭi sobyŏnŭl nuwŏ nachalman dumyŏn } \\
& \text { desease-person- IO- patient-pee-OD-make-well }
\end{aligned}
$$


Try to make the patient urinate well.

Dative constructions originating from noun: 의 손.

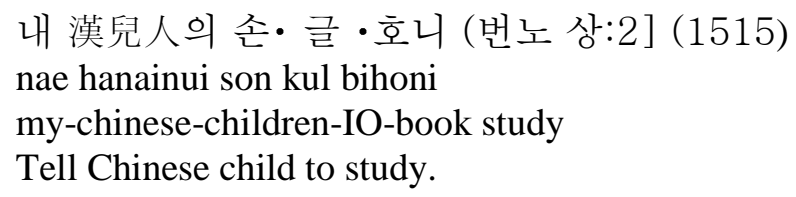

Dative constructions originated from verb: •려

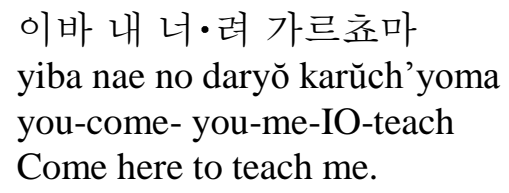

5. Modern Korean: $17^{\text {th }}$ to $19^{\text {th }}$ (근대국어近代國語)

\subsection{Historical background}

What is so significant about this time period? It is that war altered the course of language development, in this part of the world, and thus caused the progress of that language to be suspended. Prior to the war with the Japanese in 1592 Seoul was a city with a population of 80,000 . It should be also be noted that this extensive migration of Korean people, due to the Japanese invasion of 1592, exhibited great influence on the development of contemporary Korean. 


\subsection{Language}

At that time, language change is accelerated because of the war leading to intellectual influence of the various dialects. For example, some dialects of South directly affected the dialects of the central region. For example, $\Delta$ " $/ \mathrm{z}$ is lost after the war in the 17th century. After the Japanese invasions, the Kingdom of Korea closes on itself and the ruling classes refuse any outside influence. The country became isolationist and the successive kings prevent any contact with foreign countries other with than China Manchu to which they pay tribute. It is also during this period that has the nickname "Hermit Kingdom" came to refer to Korea. This isolationism, slowed technical progress and any reform of institutions, resulting in a long decline, and made Korea prey foreign powers. This isolationist policy eventually materializes in linguistic borrowing from China. Despite the still important influence of the "Middle Kingdom", a tendency to change Chinese loan words grows gradually. After the devastating effects of the war, Seoul lost approximately half its population largely due to extensive migration to other parts of the world necessary to relieve economic and social pressure caused by the war effort. Therefore, the war of 1592 has been generally agreed upon as the dividing line between the Late Middle Korean to Modern one. By so doing the focus of the language switches from written to oral (also from Cho, 2008).

5.3. Dative markers originating from demonstrative pronoun

Intimate Form: 게/의 게>의게

Intimate Form: 의거긔 until $18^{\text {th }}$ century.

$$
\text { 남지늬 거긔 머굴 것 보내더라 [삼강 열:8] }
$$


namchinŭi kŏkŭi mŏkŭl kŏt bonaedŏra

husband-IO-food-sent

I sent food to my husband.

5.4. Dative markers originated from noun

- Intimate Form: 손· $>$ 의 손대 until $18^{\text {th }}$ century.

(8) 내 너손·디워 •라 주마 [노걸 하:21] (1670)

nae nŏsondai diwŏ para chuma

I-you-IO-something-sell

I sell you something.

5.5. Dative Markers originated from verb

- General Form: 다려

(9) 좌우 다려 무르- 엇지 져리 분향-고 분쥬-・뇨 [인봉쇼전] choau dalyŏ murŭdai ŏtchi chyŏri bunhyanghako bunchyuhadanyo choau- (name of a person) - IO-ask-why-so-incense-move $(\mathrm{He})$ askes Choau why so much incense has been moved 
6. Contemporary Korean Language: from $20^{\text {th }}$ to 2013 (현 대국어現代國語)

6.1. Dative markers originating from demonstrative pronoun

- Intimate Form: 에 게

(10) 그녀는 나에게 책을 선물했다

kŭnyŏnŭn na eke ch'aek ŭl sŏnmulhaetta

she subject marker me to book DO marker offer

She offered a book to me.

(11) 그녀는 책을 나에게 선물했다

kŭnyŏnŭn ch'aek ŭl na eke sǒnmulhaetta

she subject marker book DO marker me to offer

She offered a book to me.

- Honorific Form: 께

(12) 그녀는 선생님께서 책을 선물했다

kŭnyŏnŭn sŏnsaengnimkkesŏ ch'aek ŭl sŏnmulhaetta she-teacher-IO-book-DO-offer she offered a book to teacher

(13) 그녀는 책을 선생님께서 선물했다

kŭnyŏnŭn ch'aek ŭl sŏnsaengnimkkesŏ sŏnmulhaetta she-book-DO-teacher-IO-offer

She offered a book to teacher. 
6.2. The change process of the dative case markers originating by verb

- General Form: 다려/더러

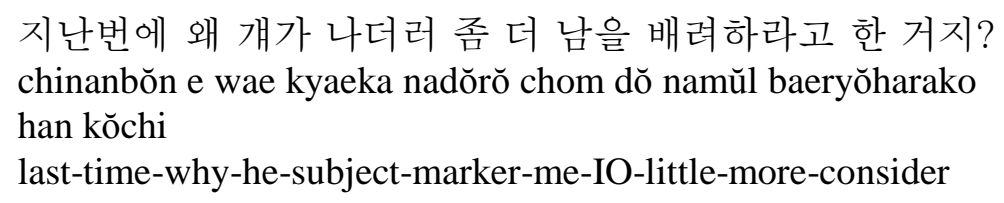

Why did he tell me to be more considerate last time?

\section{Conclusion}

We find the first dative marker in Korean in the $5^{\text {th }}$ century with the stele of the king Kwanggaet'o. Before that period, we can only suppose that Korean people were using the grammar of Chinese until the rise of the Idu writing system $\left(6^{\text {th }}-7^{\text {th }}\right)$. However, we will have to wait until the Koryŏ Dynasty (918-1392) to see the first Korean dative marker.

- $\quad$ First evidence of dative marker in Korean with 與yŭ in the $5^{\text {th }}$ century.

- $13^{\text {th }}$ century: Chinese Characters 亦中 (역중 yŏkchung) is used as the first dative marker in Early Middle Korean. The sizes of those characters are smaller in order to show the grammatical role in the sentence. It belongs to Idu writing system.

- $\quad 15^{\text {th }}$ century: Korean Language has his own alphabet and thus Chinese Characters are replaced by Korean letters. Datives markers are also using the Korean Alphabet.

- Dative markers in Korean have different grammatical origins: 
verb, demonstrative pronoun, numeral and noun.

- Dative markers in Korean have different levels of speech since $15^{\text {th }}$ century.

- $\quad$ From Old Korean to Early Middle Korean, dative markers in Korean used Chinese characters. After $8^{\text {th }}$ century, dative markers were probably using the archaic writing system called Idu in Korean.

\section{Bibliography}

Ān, Bǐngjié, Shàng, Yùhé. 2009. Hányǔ fäzhăn shľ (History of the development of the Korean Language), Běijīng: Peking University Press.

Ahn, Pyŏng-Hǔi. 1992. Kuğ̌-sa yŏn'gu (A study on the history of Korean). Seoul: Ilchisa.

Cho, Dong-Il, Bouchez, Daniel. 2002. Histoire de la littérature coréenne: des origines à 1919 (History of Korean literature from its origins to 1919). Paris: Fayard.

Cho, Kyu-T'ae. 2008. Origin and evolution of the datives markers in Korean. Baedalmal Editions 7:61.

Fabre, André. 2001. Histoire de la Corée (History of Korea). Paris: L'Asiathèque.

Ko, Yŏng-Kŭn.1977. Grammatical theories on Middle Korean. Chipmundang Journal 82.230.

Lee, Dŭk-Tch'un.1992. Hanchoŏnŏmuncha kwankaesa (History of the relationships between Chinese and Korean writing systems). Yŏnbyŏn taehakkyo ch'ulp'ansa.

Lee, Sŭng-Jae.1992. Koryŏ shidae ŭi Idu (Idu writing system under Koryŏ). Seoul: T'aehaksa.

Nam, P'ung-Hyŏn. 2000. Idu yŏn'gu (Idu research). Seoul: T'aehaksa.

$\mathrm{Na}$, Ch'a-Yon. 2008. Chungsae kukŏ munbŏp ŭi hae (Understanding the grammar of Mediaeval Korean). Kyohak yŏnkusa.

Peyaube, Alain. 1986. Evolution des constructions datives du $14 e$ siècle av. J.C. au 18 siècle (Evolution of the datives construc- 
tions from the $14^{\mathrm{e}}$ century to $18^{\mathrm{e}}$ century). Paris: Collège de France.

Ramsey, Robert and Lee, Ki-Moon, 2011. History of the Korean Language, Cambridge University Press. 
International Journal of Korean Humanities and Social Sciences, vol. 1/2015 